\title{
Endoparasites of wildcats in Croatia
}

\section{Franjo Martinković́1, Magda Sindičićéc, Snježana Lučinger ${ }^{1}$, Iva Štimac ${ }^{1}$, Miljenko Bujanić ${ }^{3}$ Tatjana Živičnjak ${ }^{1}$, Dagny Stojčević Jan' ${ }^{1}$, Nikica Šprem ${ }^{5}$, Ratko Popović4, and Dean Konjević ${ }^{3}$}

\author{
${ }^{1}$ Department of Parasitology and Parasitic Diseases with Clinic, Faculty of Veterinary Medicine, \\ University of Zagreb, Zagreb, Croatia \\ ${ }^{2}$ Department for Game Biology, Pathology and Breeding, Faculty of Veterinary Medicine, \\ University of Zagreb, Zagreb, Croatia \\ ${ }^{3}$ Department of Veterinary Economics and Epidemiology, Faculty of Veterinary Medicine, \\ University of Zagreb, Zagreb, Croatia \\ ${ }^{4}$ Croatian Forest, Department Sisak, Sisak, Croatia \\ ${ }^{5}$ Department of Fisheries, Beekeeping, Game Management and Special Zoology, \\ Faculty of Agriculture, Zagreb, Croatia
}

\section{MARTINKOVIĆ, F., M. SINDIČIĆ, S. LUČINGER, I. ŠTIMAC, M. BUJANIĆ, T.ŽIVIČNJAK, D.STOJČEVIĆ JAN, N. ŠPREM, R. POPOVIĆ, D. KONJEVIĆ: Endoparasites of wildcats in Croatia. Vet. arhiv 87, 713-729, 2017.}

\section{ABSTRACT}

Reports on the parasitic fauna of wildcats (Felis silvestris silvestris) are rare and often based on a small sample size, therefore the goal of this research was to investigate the prevalence of endoparasites in wildcats in Croatia. Necropsy was conducted on 34 adult wildcats killed in traffic or provided by hunters following regular hunting operations. All animals tested negative for rabies. The contents of the stomach and intestine were examined under a microscope. Feces from the rectum were analyzed using flotation with a saturated $\mathrm{ZnSO}_{4}$ solution, while the diaphragm was examined using artificial digestion. Direct immunofluorescence was used for the first time to detect Giardia sp. cysts in wildcats. All animals were infected with at least one species of parasites, while the most diverse infestation included six different species of parasites in a single animal. The following parasite species were found (\% of prevalence of adult parasites and their developmental stages in all analyzed samples): Taenia taeniaeformis (55.9\%), Capillaria sp. (50\%), Toxocara cati (50\%), Isospora sp. (29.4\%), Strongyloides sp. (23.5\%), Giardia sp. (17.6\%), Ancylostoma tubaeformae (14.7\%), Physaloptera sp. (11.8\%), Hymenolepididae (8.8\%), Alaria alata (5.9\%), Aelurostrongylus abstrusus (5.9\%), Toxascaris leonina (5.9\%), Trichinella sp. (5.9\%), Mesocestoides lineatus (5.9\%), Anoplocephalidae (2.9\%), Dipylidium caninum (2.9\%), Trichuris sp. (2.9\%), Isospora felis (2.9\%), Eimeria sp. (2.9\%) and Sarcocystis sp. (2.9\%). Among

\footnotetext{
${ }^{*}$ Corresponding author:

Magda Sindičić, Assistant Professor, DVM, PhD, Department for Game Biology, Pathology and Breeding, Faculty of Veterinary Medicine University of Zagreb, Heinzelova 55, 10000 Zagreb, Croatia, Phone: +385 12390 156; Fax: +385 1 2441 390; E-mail: magda.sindicic@vef.hr
} 
those, Eimeria sp., Trichuris sp. eggs, anoplocephalid and hymenolepidid type eggs are spurious parasites, coming from ingested prey. Four of the identified species have never been previously reported in wildcats Giardia sp., Strongyloides sp., Sarcocystis sp. and Dipylidium caninum.

Key words: parasites, wildcat, Felis silvestris silvestris, Croatia

\section{Introduction}

The wildcat (Felis silvestris silvestris) is the most common and widely-distributed wild felid, found throughout most of Africa, Europe, southwest and central Asia. In Europe the species is native to most countries, except Fennoscandia, but today the species has a sporadic distribution throughout the continent (YAMAGUCHI et al., 2015). In Croatia the wildcat is present throughout the country, except on the islands (JANICKI et al., 2007). Unfortunately, detailed distribution maps are not available for Croatia, and also there are no scientific data about population size and trends, demographic dynamics, ecology, and diseases.

The effects of pathogens and diseases on the conservation of carnivores are of major concern, but knowledge of their parasitic fauna is scarce (FUNK et al., 2001). Comprehensive parasitological studies depend on the ability to collect a large number of samples. Carcasses are the best source for research of gastrointestinal fauna, while copromicroscopic surveys may be a useful alternative (NAPOLI et al., 2016). In protected species (like the wildcat in most European countries, including Croatia since 2013) it may be difficult to obtain carcasses, as they are rarely found in nature (apart from road kills). Studying wildcat gastrointestinal parasites from feces is also challenging because, due to the low population densities and their solitary way of life, it may be challenging to find fresh samples. As a result, studies on parasites of wildcats are not only rare, but also based on a limited sample size (BURT et al., 1980; SCHUSTER et al., 1993; PAPADOPOULOS et al., 1997; RODRIGUEZ and CARBONELL, 1998; KRONE et al., 2008; KIRKOVA et al., 2011; NAPOLI et al., 2016; VERONESI et al., 2016).

In Croatia, there are no data about parasites in wildcats. Therefore, the aim of this survey was to investigate the prevalence of gastrointestinal and Trichinella parasites in wildcats in Croatia.

\section{Materials and methods}

Samples. A total of 34 entire carcasses or intestines with diaphragm of adult wildcats killed in traffic accidents or culled during regular game management activities (prior to the hunting ban in 2013) were collected and stored at $-20{ }^{\circ} \mathrm{C}$. DNA analysis confirmed all the samples were from wildcats and that there were no domestic cats in the sampling (SINDIČIĆ et al., 2016).

Study area. The origin of samples collected is presented on Fig. 1. 


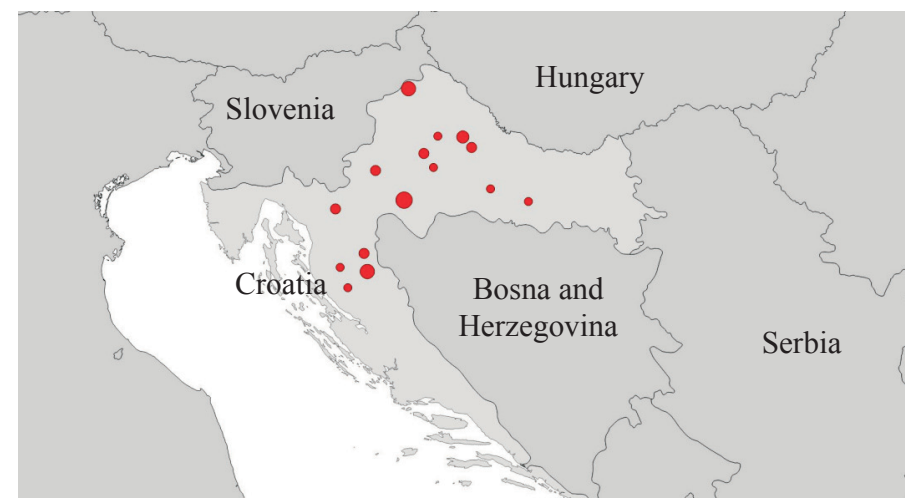

Fig. 1. Location of origin of wildcat samples. The size of the circle corresponds to the number of samples from each location.

Necropsy and parasitological examination. Before necropsy, each animal was tested for rabies and all the tests were negative. Necropsies were conducted at the Faculty of Veterinary Medicine, University of Zagreb, according to a standard veterinary protocol. The gastrointestinal tract (stomach and intestines) was removed from the animal, stored in separated plastic containers, opened along its length and flushed with water, while its mucosa was scraped and separated in another plastic container. From some wildcats only the intestines and diaphragms were available.

The contents of the stomach and intestines were examined in Petri dishes on a dark background under a stereomicroscope, while the scraped mucosa was checked for parasites under the microscope. Parasites were then washed out with saline to remove the gastrointestinal contents in order to facilitate definition to the genus or species level, depending on the condition.

Copromicroscopic examination. Feces was removed from the rectum and separated into two parts of $5 \mathrm{~g}$ each. One part was analyzed using the flotation method with a saturated $\mathrm{ZnSO}_{4}$ solution (S.G. = 1.3), and the other was used to detect Giardia sp. cysts. Fecal samples were first prepared using the flotation technique with sucrose, and then analyzed by the direct immunofluorescence method (Meridian Bioscience, Inc., Merifluor ${ }^{\circledR}$ Cryptosporidium/Giardia).

Artificial digestion. The presence of Trichinella sp. parasites was analyzed using diaphragm samples $(10 \mathrm{~g})$ by the reference method for artificial digestion of Trichinella in meat (The European Community Regulation (EC) No. 2075/2005).

Parasite determination. The parasite identifications and staining were based on the available descriptions (MEHLHORN et al., 1993; HRČKOVA et al., 2011; BRIANTI et al., 2012; SCHMÄSCHKE, 2013). Briefly, adult parasites were stained with lactophenol (nematodes, 
tapeworms) or lactic acid-carmine stain (tapeworms), if needed. Nematodes were identified by anterior end morphology (Toxocara canis, Toxascaris leonina, Ancylostoma tubaeformae, Physaloptera sp., Strongyloides sp.), cestodes by hooks size, hermaphrodite and gravid proglottid morphology (Taenia taeniaeformis, Mesocestoides lineatus, Dipylidium caninum), and developmental parasite stages (larvae, eggs, oocysts) by size (length, width), the thickness and smoothness of the egg shell, or specific morphological characteristics such as egg protuberance morphology (Trichuris sp., Capillaria sp.), operculum presence (Alaria alata), larval tail morphology (Aelurostrongylus abstrusus), or stichocyte presence (Trichinella sp.). Some of the parasites were microphotographed and edited with QuickPhoto Micro 2.3 software (Fig. 2 - Fig. 4). Due to significant degradation, identification to species level was not possible for some samples.

Common parasite species were defined as those whose prevalence was at least $20 \%$ (WAID and PENCE, 1988).

\section{Results}

All animals were infected with at least one parasite species. The most diverse infection, including six different species of parasites, was found in three animals $(8.82 \%)$, while mono infections dominated in eight examined samples (23.53\%) (Tables 1 and 3 ).

Table 1. Number of parasite species per wildcat

\begin{tabular}{|c|c|}
\hline No. animals/No of parasite species per animal & Prevalence (\%) $\mathrm{n}=34$ \\
\hline $3 / 6$ & 8.82 \\
\hline $5 / 5$ & 14.71 \\
\hline $6 / 4$ & 17.65 \\
\hline $6 / 3$ & 17.65 \\
\hline $6 / 2$ & 17.65 \\
\hline $8 / 1$ & 23.53 \\
\hline
\end{tabular}

Parasites from 19 different genera and at least 20 different species were identified (Tables 2 and 3). The most prevalent parasites in this survey were T. cati (Fig. 2a), T. taeniaeformis (Fig. 2b, Fig. 2c), Capillaria sp., Isospora sp. and Strongyloides sp. (Fig. 3e, Fig. 3f). Other parasites, such as T. leonina (Fig. 2a), M. lineatus (Fig. 3a, Fig. 3b), D. caninum (Fig. 3c, Fig. 3d), A. tubaeformae (Fig. 4a, Fig. 4b), A. abstrusus (Fig. 4c, Fig. 4d), A. alata (Fig. 4e), Giardia sp. (Fig. 4f), Physaloptera sp., Isospora felis, Sarcocystis sp., Eimeria sp., Trichuris sp., Hymenolepididae and Anoplocephalidae, were less prevalent (Table 2). Trichinella sp. larvae were found in only two wildcat samples (Table 3). 


\section{F. Martinković et al.: Endoparasites of wildcats in Croatia}

Table 2. Prevalence of gastrointestinal helminth and protozoan parasites in wildcats $(n=34)$

\begin{tabular}{|c|c|c|c|c|c|c|}
\hline Species & (NPE) & $\mathrm{P}(\%)$ & $(\mathrm{NCE})$ & $\mathrm{P}(\%)$ & $\begin{array}{c}\text { Total } \\
\text { (NPE+NCE) }\end{array}$ & $\mathrm{P}(\%)$ \\
\hline Taenia taeniaeformis & 18 & 52.9 & 4 & 11.8 & 19 & 55.9 \\
\hline Mesocestoides lineatus & 1 & 2.9 & $1^{\mathrm{a}}$ & 2.9 & 2 & 5.9 \\
\hline Hymenolepidid eggs $^{\mathrm{s}}$ & $2^{\mathrm{e}}$ & 5.9 & 2 & 5.9 & 3 & 8.8 \\
\hline Anoplocephalid eggs ${ }^{\text {s }}$ & 0 & 0.0 & 1 & 2.9 & 1 & 2.9 \\
\hline Dipylidium caninum & 1 & 2.9 & 0 & 0.0 & 1 & 2.9 \\
\hline Alaria alata & $1^{\mathrm{e}}$ & 2.9 & 2 & 5.9 & 2 & 5.9 \\
\hline Ancylostoma tubaeforme & 2 & 5.9 & 5 & 14.7 & 5 & 14.7 \\
\hline Aelurostrongylus abstrusus & $1^{1}$ & 2.9 & 2 & 5.9 & 2 & 5.9 \\
\hline Toxocara cati & 16 & 47.1 & 15 & 44.1 & 17 & 50.0 \\
\hline Toxascaris leonina & 2 & 5.9 & 2 & 5.9 & 2 & 5.9 \\
\hline Trichuris sp. ${ }^{\mathrm{s}}$ & 0 & 0.0 & 1 & 2.9 & 1 & 2.9 \\
\hline Capillaria sp. & $7^{\mathrm{e}}$ & 20.6 & 17 & 50.0 & 17 & 50.0 \\
\hline Physaloptera sp. & 4 & 11.8 & 1 & 2.9 & 4 & 11.9 \\
\hline Strongyloides sp. & 7 & 20.6 & 1 & 2.9 & 8 & 23.5 \\
\hline Isospora felis & 0 & 0.0 & 1 & 2.9 & 1 & 2.9 \\
\hline Isospora sp. & 0 & 0.0 & 10 & 29.4 & 10 & 29.4 \\
\hline Eimeria sp. $^{\mathrm{s}}$ & 0 & 0.0 & 1 & 2.9 & 1 & 2.9 \\
\hline Giardia sp. & 0 & 0.0 & 6 & 17.6 & 6 & 17.6 \\
\hline Sarcocystis sp. & 0 & 0.0 & 1 & 2.9 & 1 & 2.9 \\
\hline
\end{tabular}

NPE: number of parasitologically positive intestines containing adult parasites if not differently indicated; NCE: number of positive fecal samples containing eggs, oocysts or larvae if not differently indicated; NPE+NCE: number of positive intestines and fecal samples; P: prevalence; ${ }^{\mathrm{e}}$ : only eggs were detected; ${ }^{1}$ : only larvae were detected; ${ }^{\text {a. }}$ only adults were detected; ${ }^{\text {s: }}$ spurious parasites. 
F. Martinković et al.: Endoparasites of wildcats in Croatia

\begin{tabular}{|c|c|c|c|c|c|c|c|c|c|c|c|c|c|c|c|c|c|c|c|c|c|c|}
\hline $\begin{array}{l}= \\
\bar{z} \\
3\end{array}$ & $\frac{\bigcup}{\underline{U}}$ & $\frac{1}{+}$ & $\frac{1}{1}$ & $\frac{1}{1}$ & $\frac{1}{1}$ & $\frac{1}{1}$ & $\frac{1}{1}$ & $\frac{1}{1}$ & $\frac{1}{1}$ & $\frac{t}{t}$ & $\frac{1}{1}$ & $\frac{1}{1}$ & \pm & $\frac{1}{1}$ & $\frac{1}{+}$ & $\frac{1}{1}$ & $\stackrel{+}{1}$ & $\frac{1}{1}$ & $\frac{1}{1}$ & $\frac{1}{1}$ & $\frac{1}{1}$ & . \\
\hline $\begin{array}{l}0 \\
u \\
3\end{array}$ & $\frac{\underline{U}}{\underline{\underline{U}}}$ & $\frac{1}{1}$ & $\frac{1}{+}$ & $\frac{1}{1}$ & $\frac{1}{1}$ & $\frac{1}{1}$ & $\frac{1}{1}$ & $\frac{1}{1}$ & $\frac{1}{1}$ & $\frac{1}{1}$ & $\frac{1}{1}$ & $T_{1}^{\prime}$ & $\begin{array}{l}+ \\
0 \\
+\end{array}$ & $\frac{1}{1}$ & $\stackrel{+}{t}$ & $\frac{1}{1}$ & $\frac{1}{1}$ & $\frac{1}{1}$ & $\frac{1}{1}$ & $\frac{1}{1}$ & $\frac{1}{1}$ & 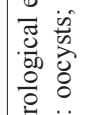 \\
\hline $\begin{array}{l}8 \\
3\end{array}$ & $\frac{\text { 민 }}{\text { 미 }}$ & $\frac{1}{1}$ & $\frac{1}{1}$ & $\frac{1}{1}$ & $\frac{1}{1}$ & $\frac{1}{1}$ & $\frac{1}{1}$ & $\frac{1}{1}$ & $\frac{1}{1}$ & $\frac{1}{1}$ & $\frac{1}{1}$ & $\frac{1}{1}$ & $\frac{1}{1}$ & $\frac{1}{1}$ & $\frac{1}{1}$ & $\frac{1}{1}$ & $\frac{t}{1}$ & $\frac{1}{1}$ & $\frac{1}{1}$ & $\frac{1}{1}$ & $\frac{1}{1}$ & 岀胥 \\
\hline $\begin{array}{l}\infty \\
0 \\
3\end{array}$ & $\frac{\sqrt{U}}{\underline{\underline{U}}}$ & $\frac{1}{+}$ & $\frac{1}{1}$ & $\frac{1}{1}$ & \pm & $\frac{1}{1}$ & $\frac{t}{0}+$ & $\frac{1}{1}$ & $\frac{1}{1}$ & $\frac{+}{+}$ & $\frac{1}{1}$ & $\frac{1}{1}$ & $\begin{array}{l}+ \\
0 \\
+\end{array}$ & $\frac{1}{1}$ & $\frac{1}{+}$ & $\frac{1}{1}$ & $\stackrel{t}{1}$ & $\frac{1}{1}$ & $\frac{1}{1}$ & $\frac{1}{1}$ & $\frac{1}{1}$ & : \\
\hline 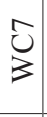 & $\frac{\underline{U}}{\underline{\underline{U}}}$ & $\frac{1}{1}$ & $\frac{1}{1}$ & $\frac{1}{1}$ & $\frac{1}{1}$ & $\frac{1}{1}$ & $\frac{1}{1}$ & $\frac{1}{1}$ & $\frac{1}{1}$ & $\frac{1}{1}$ & $\frac{1}{1}$ & $\frac{1}{1}$ & $\begin{array}{l}+ \\
0 \\
+\end{array}$ & $\frac{1}{1}$ & $\frac{1}{1}$ & $\frac{1}{1}$ & $\frac{1}{1}$ & $\frac{1}{1}$ & $\frac{1}{1}$ & $\frac{1}{1}$ & $\frac{1}{1}$ & $\ddot{z}$ \\
\hline $\begin{array}{l}0 \\
0 \\
3\end{array}$ & $\frac{\underline{U}}{\underline{\underline{D}}}$ & $\frac{1}{1}$ & $\frac{1}{1}$ & $\begin{array}{l}1 \\
0 \\
+ \\
+\end{array}$ & $\frac{1}{1}$ & $\frac{1}{1}$ & $\frac{1}{1}$ & $\frac{1}{1}$ & $\frac{1}{1}$ & $\frac{+}{+}$ & $\frac{1}{1}$ & $\frac{1}{1}$ & $\frac{1}{1}$ & $\frac{1}{1}$ & $\frac{1}{1}$ & $\frac{1}{1}$ & $\frac{t}{1}$ & $\frac{1}{1}$ & $\frac{+}{1}$ & $\frac{1}{1}$ & $\frac{1}{1}$ & 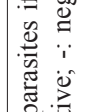 \\
\hline $\begin{array}{l}n \\
3 \\
3\end{array}$ & $\frac{\bigcup}{\underline{\underline{U}}}$ & $\frac{1}{1}$ & $\frac{1}{1}$ & $\begin{array}{l}+ \\
0 \\
+\end{array}$ & $\frac{1}{1}$ & $\frac{1}{1}$ & $\frac{1}{1}$ & $\frac{1}{1}$ & $\frac{1}{1}$ & $\frac{+}{+}$ & $\frac{1}{1}$ & $\frac{1}{1}$ & $\frac{1}{1}$ & $\frac{1}{1}$ & $\frac{1}{1}$ & $\frac{1}{1}$ & \pm & $\frac{1}{1}$ & \pm & $\frac{1}{1}$ & $\frac{1}{1}$ & $\begin{array}{l}\pi \\
00 \\
0\end{array}$ \\
\hline $\begin{array}{l} \pm \\
3\end{array}$ & $\frac{\underline{U}}{\underline{\underline{U}}}$ & $\frac{1}{+}$ & $\frac{1}{1}$ & $\frac{1}{1}$ & $\frac{1}{1}$ & $\frac{1}{1}$ & $\frac{1}{1}$ & $\frac{1}{1}$ & $\frac{1}{1}$ & $\frac{t}{+}$ & $\frac{1}{1}$ & $\frac{1}{1}$ & \pm & $\frac{1}{+}$ & $\frac{1}{1}$ & $\frac{1}{1}$ & $\frac{t}{1}$ & $\frac{1}{1}$ & \pm & $\frac{1}{1}$ & $\frac{1}{1}$ & $n=7$ \\
\hline $\begin{array}{l}n \\
3\end{array}$ & 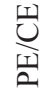 & $\frac{1}{1}$ & $\frac{1}{1}$ & $\frac{1}{1}$ & $\frac{1}{1}$ & $\frac{1}{1}$ & $\frac{1}{1}$ & $\frac{1}{1}$ & $\frac{1}{1}$ & $\frac{t}{t}$ & $\frac{1}{1}$ & $\frac{1}{1}$ & $\frac{1}{1}$ & $\frac{1}{1}$ & $\frac{1}{1}$ & $\frac{1}{1}$ & $\frac{t}{1}$ & $\frac{1}{1}$ & $\frac{ \pm}{1}$ & $\frac{1}{1}$ & $\frac{1}{1}$ & 0 \\
\hline $\begin{array}{l}\text { U } \\
3\end{array}$ & $\frac{\text { 밈 }}{\underline{\underline{\nu}}}$ & $\frac{1}{+}$ & $\frac{1}{1}$ & $\frac{1}{1}$ & $\frac{1}{1}$ & $\frac{1}{1}$ & $\frac{1}{1}$ & $\frac{1}{1}$ & $\frac{1}{1}$ & $\frac{1}{1}$ & $\frac{1}{1}$ & $\frac{1}{1}$ & $\frac{1}{1}$ & $\frac{1}{1}$ & $\frac{1}{1}$ & $\frac{1}{1}$ & $\frac{1}{1}$ & $\frac{1}{1}$ & $\frac{1}{1}$ & $\frac{1}{1}$ & $\frac{1}{1}$ & 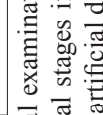 \\
\hline$\vec{z}$ & 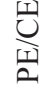 & $\frac{1}{+}$ & $\frac{1}{1}$ & $\frac{1}{1}$ & $\frac{1}{1}$ & $\frac{1}{1}$ & $\frac{1}{1}$ & $\frac{1}{1}$ & $\frac{1}{1}$ & $\frac{t}{+}$ & $\frac{1}{1}$ & $\frac{1}{1}$ & $\frac{1}{1}$ & $\frac{1}{1}$ & $\frac{1}{1}$ & $\frac{1}{1}$ & $\frac{1}{1}$ & $\frac{1}{1}$ & $\frac{1}{1}$ & $\frac{1}{1}$ & $\frac{1}{1}$ & \\
\hline 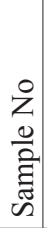 & 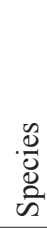 & 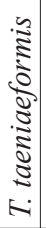 & 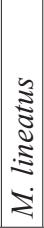 & 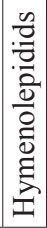 & 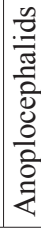 & 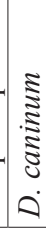 & $\begin{array}{l}\frac{\pi}{3} \\
\frac{3}{3} \\
\dot{\pi}\end{array}$ & 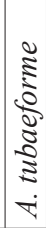 & 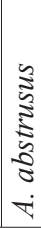 & 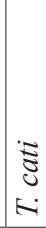 & 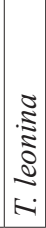 & 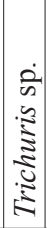 & 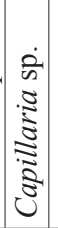 & 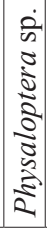 & 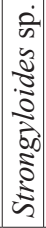 & $\frac{-2}{20}$ & $\begin{array}{l}\dot{2} \\
\text { की } \\
0 \\
0 \\
\vdots \\
0 \\
0 \\
0 \\
0\end{array}$ & $\mid$ & 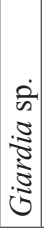 & 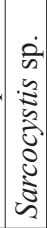 & 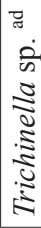 & 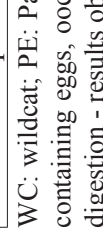 \\
\hline
\end{tabular}


F. Martinković et al.: Endoparasites of wildcats in Croatia

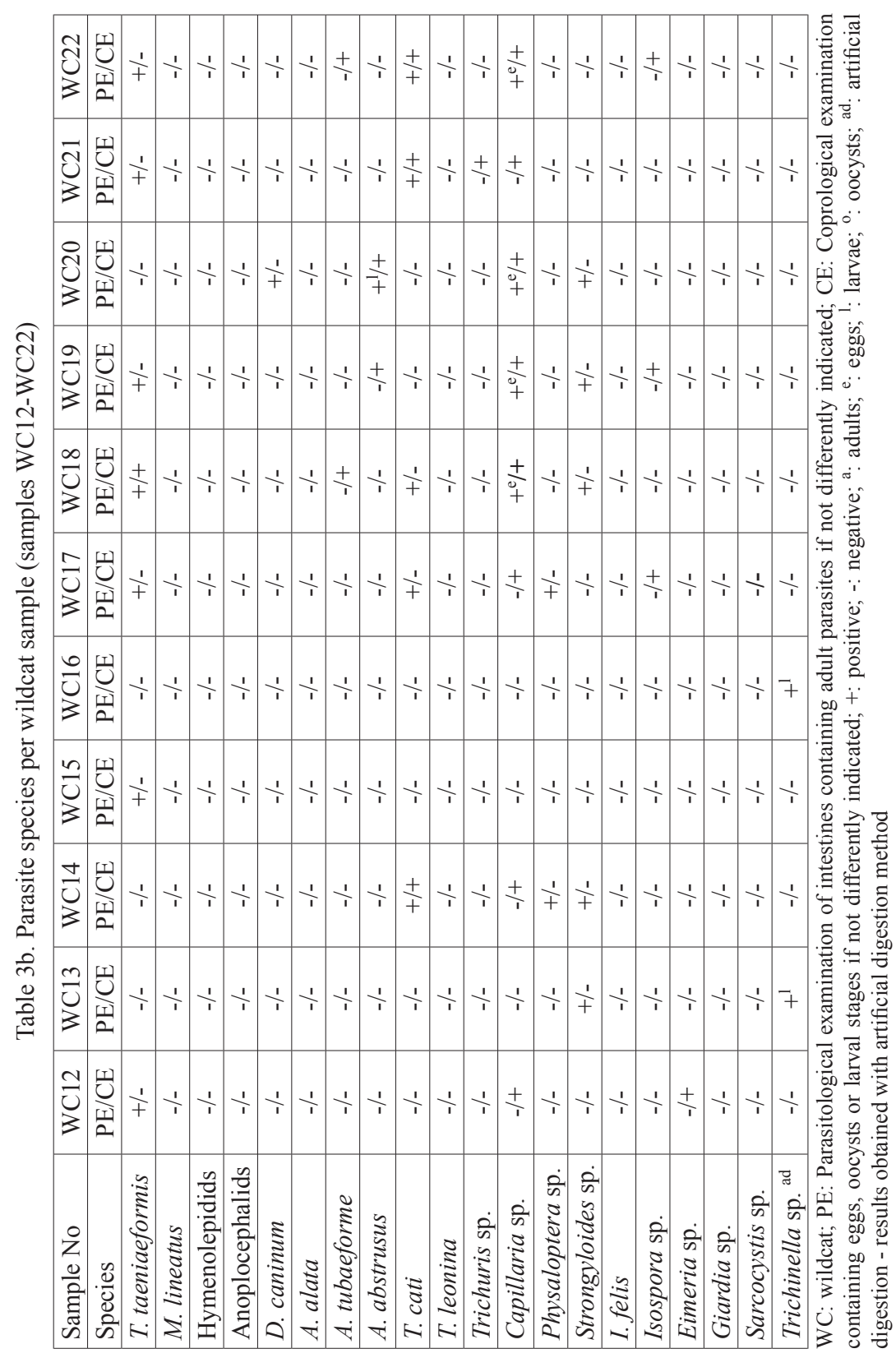

Vet. arhiv 87 (6), 713-729, 2017 
F. Martinković et al.: Endoparasites of wildcats in Croatia

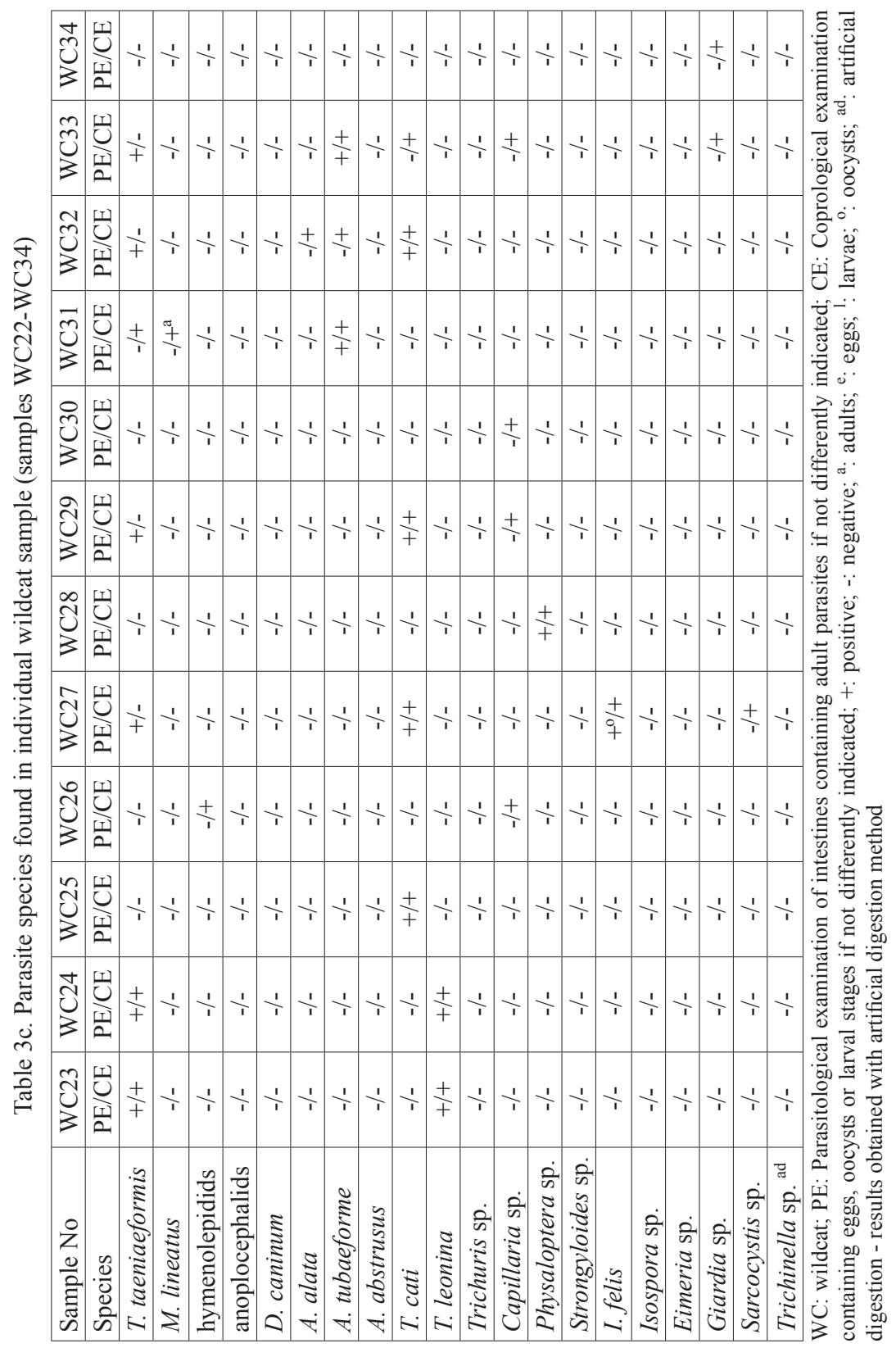



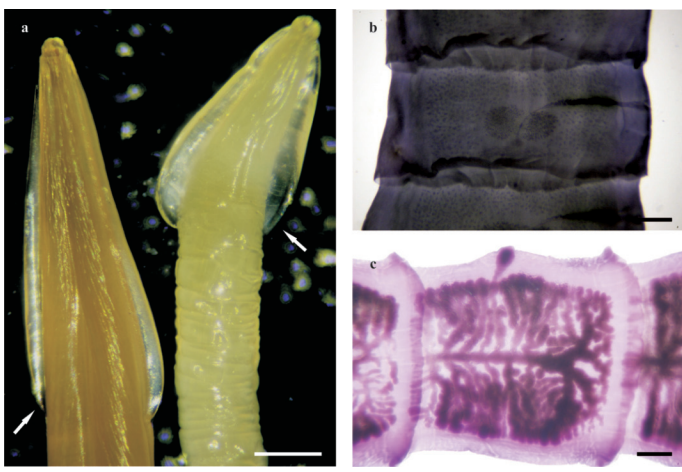

Fig. 2. Parasites of wildcat. (a) Morphological comparison of Toxascaris leonina and Toxocara cati anterior end. Long and narrow cervical alae in T. leonina on the left (arrow) and short and wide cervical alae in $T$. cati on the right (arrow). (b) Taenia taeniaeformis hermaphrodite proglottids. (c) Taenia taeniaeformis gravide proglottids. Scale bar $=500 \mu \mathrm{m}$.
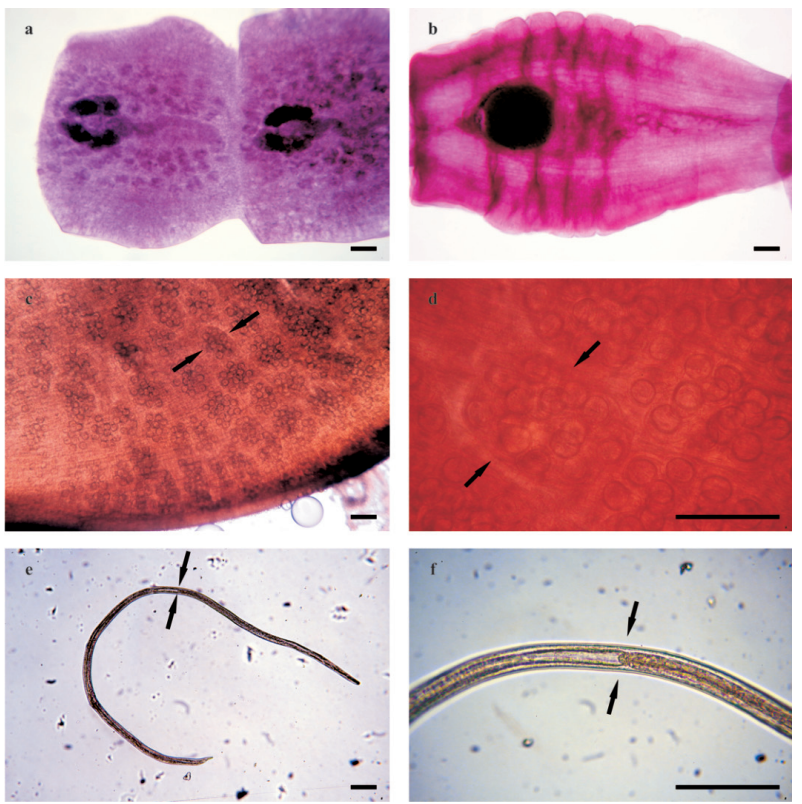

Fig. 3. Parasites of wildcat. (a) Mesocestoides lineatus hermaphrodite proglottids. (b)

Mesocestoides lineatus gravide proglottids. (c) Dipylidium caninum gravide proglottid containing cocoons with eggs (in between arrows). (d) Dipylidium caninum gravide proglottid containing cocoons with eggs (in between arrows). (e) Strongyloides sp. female with long esophagus (arrows indicating esophagus to intestine transition). (f) Strongyloides sp. female with long esophagus (arrows indicating esophagus to intestine transition). Scale bar $=100 \mu \mathrm{m}$. 

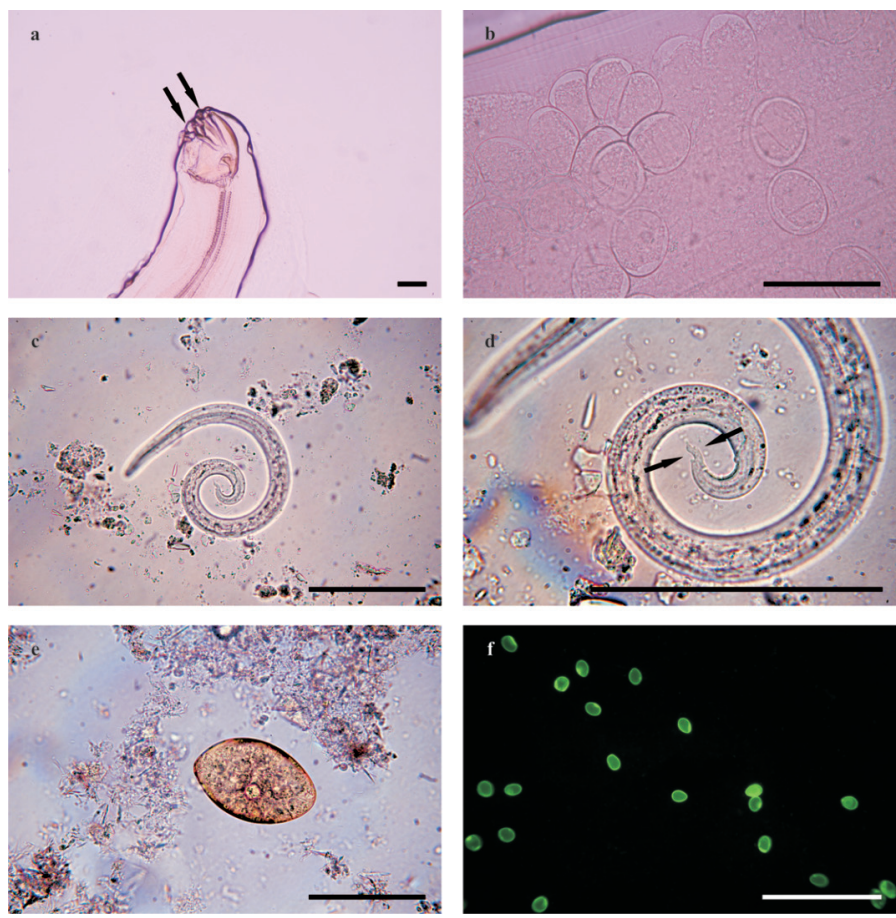

Fig. 4. Parasites of wildcat. (a) Latero-lateral view of Ancylostoma caninum anterior end. Overlapping teeth on dorsal margin of buccal capsule (arrows). (b) Ancylostoma caninum eggs

in female. (c) Aelurostrongylus abstrusus larva. (d) Aelurostrongylus abstrusus larva with characteristic tail shape (arrow). (e) Alaria alata egg. (f) Giardia sp. cysts under the fluorescence microscope after performed IFA test. Scale bar $=100 \mu \mathrm{m}$.

\section{Discussion}

The $100 \%$ prevalence of endoparasitic infections in this study was the same as reported previously in wildcats in Greece, Spain and Germany (PAPADOPOULOS et al., 1997; RODRIGUEZ and CARBONELL, 1998; KRONE et al., 2008). Similarly, a high prevalence was also found in Bulgaria (95.5\%) (KIRKOVA et al., 2011) and Italy $(90.9 \%)$ (NAPOLI et al., 2016).

Species diversity in this study was 0.6 (34 animals tested and 20 parasites species identified). The diversity of parasitic fauna and species prevalence differs between studies. In Greece, five different species of endoparasites were identified in four cats (PAPADOPOULOS et al., 1997), in France seven species in 39 samples (LEPLE, 2001), in Germany 8 in 15 wildcats (KRONE et al., 2008), in Slovenia 8 in 12 samples (BRGLEZ and 
ŽELEZNIK, 1976), in Italy 10 species in 121 samples (NAPOLI et al., 2016), in Bulgaria 11 in 22 samples (KIRKOVA et al., 2011) in Spain 15 in 19 samples (RODRIGUEZ and CARBONELL, 1998); while the present survey had the highest diversity in terms of the different species identified (20 from 34 samples).

Among all parasites detected, the common parasites, with a prevalence of $20 \%$ or higher (WAID and PENCE, 1988) were T. taeniaeformis, T. cati, Capillaria sp., Isospora sp., and Strongyloides sp. Taenia taeniaeformis, M. lineatus, T. cati, T. leonina, Capillaria sp., A. tubaeformae, A. abstrusus, Physaloptera sp., Trichinella sp., I. felis, Isospora sp. have been commonly found in wildcat endoparasite surveys across Europe with differing prevalence, and the findings of this survey are in accordance with other studies. Four types of spurious parasites were found by copromicroscopic analysis: Eimeria sp., Trichuris sp. eggs, anoplocephalid and hymenolepidid type eggs. It may be assumed that they all originate from prey, rodents or lagomorphs, as previously reported by RODRIGUEZ and CARBONELL (1998) and KIRKOVA et al. (2011).

In this study, Trichinella spp. was found in two out of 34 analyzed samples (5.88\%). In other studies conducted in different European countries, Trichinella was found in a higher prevalence, with the highest prevalence in Bulgaria (BRGLEZ and ŽELEZNIK, 1976; KIRKOVA et al., 2011; BLAGA et al., 2009; BADAGLIACCA et al., 2016). Infection of wildlife with Trichinella spp. is widespread throughout Europe. There are records of T. britovi and $T$. spiralis infection in wildcats, where T. britovi infection prevails by $73 \% \mathrm{vs.} 27 \%$ (POZIO et al., 2009). In Croatia, Trichinella sp. infection in wildcats has not been detected until now, but is already known in other wild carnivores and omnivores including wolves, badgers, wild boars, bear, and lynx (BECK et al., 2009).

Four parasite species were identified which to our knowledge have previously never been reported in free-living wildcats: D. caninum, Sarcocystis sp., Strongyloides sp., and Giardia sp.

Strongyloides sp. was detected in eight wildcat samples (23.5\%) in the current study and this is the first finding of this parasite in Felis silvestris silvestris. Strongyloides species are known, but rare parasites of felines worldwide, and up to now several different species have been described (THAMSBORG et al., 2016). There are a few reports about the low prevalence of Strongyloides sp. infection in domestic cats in Europe (TAKEUCHISTORM at al., 2015a; MIRCEAN et al., 2010). Also S. stercoralis was found in one sample in Lynx pardinus in Spain (RODRIGUEZ and CARBONELL, 1998).

According to SPEARE and TINSLEY (1987), when fewer feces are used in routine diagnostics, the chances of finding Strongyloides sp. are slight. This problem can be avoided by using the Baerman test and greater quantities of feces. The females present in the intestine are very thin, and can be found only by dissecting the mucosa, a procedure not done consistently in any former studies. In this study, adults were found in seven 
intestines, with rhabditid larvae in only one separate fecal smear (Table 3a-Table 3c). The reason for the low Strongyloides sp. prevalence within fecal samples, besides the preservation state of samples, could also be due to the amount of feces used. It could be concluded that Strongyloides sp. parasites are present in Croatian wildcats in a higher prevalence than was detected by fecal examination. In the future, more attention should be paid to avoiding false negative results, especially if only examination of feces is used for monitoring the parasites.

A. alata eggs were found in feces, which is a species previously reported but it is rare in wildcats (TAKACS et al., 2011). The species has been reported in domestic cats in several publications - adult flukes were identified in Uruguay (CASTRO et al. 2009), eggs in upstate New York (LUCIO-FORSTER and BOWMAN, 2011) and on Gran Canaria island (RODRÍGUEZ-PONCE et al., 2016); while mesocercariae were identified in domestic cats in Denmark (TAKEUCHI-STORM et al., 2015b). Recently, among all the surveys conducted on wildcats (BURT et al., 1980; SCHUSTER et al., 1993; PAPADOPOULOS et al., 1997; RODRIGUEZ and CARBONELL, 1998; KRONE et al., 2008; KIRKOVA et al., 2011; NAPOLI et al., 2016), only TAKACS et al. (2011) recorded $A$. alata. Adult flukes were found in the duodenum and eggs in intestinal scrapings in one male wildcat. Alaria alata was previously described in Croatia in other species: the presence of $A$. alata mesocercariae was described in wild boar (JAKŠIĆ et al., 2002), while adult flukes were recorded in foxes (RAJKOVIĆ-JANJE et al., 2002) and golden jackals (SINDIČIĆ et al., 2017).

It has never been proven that felids can act as definitive hosts for $A$. alata in Europe, and it is still uncertain if cats can act as paratenic or final hosts of $A$. alata, as they can host Alaria marcinae. In A. marcinae infection, both cat sexes are final hosts; while lactating females are primarily paratenic hosts, and mesocercarie can be transmitted through milk to their offspring (SHOOP and CORKUM, 1987). Unfortunately, adult flukes were not found in wildcat intestines in this investigation. Among animals analyzed in this study, there were also male cats infected with $A$. alata, indicating the possibility that felids can act as final hosts for A. alata. Additionally, reports from TAKACS et al. (2011), TAKEUCHI-STORM et al. (2015b) and RODRÍGUEZ-PONCE et al. (2016) and the present findings indicate that $A$. alata could behave in the same way as $A$. marcinae in feline hosts. Certainly, further investigation is needed to elucidate if wildcats can be definitive hosts for A. alata or not.

Both D. caninum and Sarcocystis sp. were found in only one sample (2.94\%). To the authors' knowledge these species have not been previously reported in wildcat studies, but both of these parasites are a common finding in domestic cats, reaching up to $83.3 \%$ for D. caninum and $0.8-1 \%$ for Sarcocystis sp. in some surveys (KNAUS et al., 2011; LUCIO-FORSTER and BOWMAN, 2011; MIRCEAN et al., 2010). In general, the life cycle of Sarcocystis sp. exclusively includes intermediate and final hosts, where the former 
behaves as a prey and the latter as a predator. Development to mature stages and the patent period of this parasite in cats are usually transient as most of the oocysts are shed during an approximately two-week period (ECKERT et al., 2005). It could be assumed that this short patent period is the reason why the parasite has never been identified in previous studies, because the sample has to be collected exactly during this short period when the parasite is present in the intestines.

Giardia sp. is a common parasite of domestic cats in Europe. During the $2001-2014$ period, 29 surveys on domestic cats were conducted with prevalence ranging from $0 \%$ $37 \%$, depending on study area and method used (BOUZID et al., 2015). The current survey results showed the presence of Giardia sp. cysts in six wildcat samples (17.6\%); while to the authors' knowledge no other studies conducted on wildcats detected the presence of Giardia sp. Infection with Giardia sp. in wild carnivores in Croatia, other than wildcats, was described by BECK et al. (2011a) and ranged from $4.5 \%$ in foxes, $10 \%$ in wolves, and up to $12.5 \%$ in jackals. Also, there is a report of Giardia sp. infection in captive felines from the Croatian Zagreb ZOO (BECK et al., 2011b) and in domestic cats (CACCIÒ et al., 2010). The low prevalence of Giardia sp. infection in this study could indicate that wildcats ingest Giardia sp. cysts by feeding on rodents. Rodents carry Giardia muris, Giardia microti, or Giardia duodenalis assemblage G, which may be unable to establish infection in wildcats, as was described for foxes (BECK et al., 2011a). Still, the true origin of Giardia sp. in wildcats remains to be discovered.

The results of the intestine examination coincide with the copromicroscopic examination in the majority of samples (Table 2, Table 3). There are some exceptions, e.g. T. taeniaeformis eggs were less prevalent in feces than the adults in intestine. This result was expected because the sensitivity of the flotation method is only $60-80 \%$ when more than 1000 eggs/g of feces are present. With lower fecal egg content, the results could be a false negative (ECKERT et al., 2005). Other exceptions (Table 2, Table 3) are due to the sample preservation state. Namely, some wildcats were collected as road kill, then frozen until examined, and thawed. As previously reported (RODRIGUEZ and CARBONELL, 1998; KIRKOVA et al., 2011), carcass degradation caused by environmental conditions could considerably influence the results, as some parasites (e. g. tapeworms, nematodes, nematode larvae, oocysts) could deteriorate over time and could be difficult to identify.

To the authors' knowledge this is the first report of the wildcat helminth and protozoan fauna in Croatia. Also, the free-living wildcat is reported as a host for Giardia sp., Sarcocystis sp., Strongyloides sp. and D. caninum for the first time.

\section{References}

BADAGLIACCA, P., D. DI SABATINO, S. SALUCCI, G. ROMEO, M. CIPRIANI, N. SULLI, F. DALL'ACQUA, M. RUGGIERI, P. CALISTRI, D. MORELLI (2016): The role of the wolf 
in endemic sylvatic Trichinella britovi infection in the Abruzzi region of Central Italy. Vet. Parasitol. 231, 124-127.

BECK, R., A. BECK, J. KUSAK, Z. MIHALJEVIĆ, S. LUCINGER, T. ZIVICNJAK, D. HUBER, A. GUDAN, A. MARINCULIĆ (2009): Trichinellosis in wolves from Croatia. Vet. Parasitol. 159, 308-311.

BECK, R., H. SPRONG, S. LUČINGER, E. POZIO, S. M. CACCIÒ (2011a): A large survey of Croatian wild mammals for Giardia duodenalis reveals a low prevalence and limited zoonotic potential. Vector Borne Zoonotic Dis. 11, 1049-1055.

BECK, R., H. SPRONG, I. BATA, S. LUČINGER, E. POZIO, S. M. CACCIÒ (2011b): Prevalence and molecular typing of Giardia spp. in captive mammals at the zoo of Zagreb, Croatia. Vet. Parasitol. 175, 40-46.

BlAGA, R., C. GHERMAN, V. COZMA, A. ZOCEVIC, E. POZIO, P. BOIREAU (2009): Trichinella species circulating among wild and domestic animals in Romania. Vet. Parasitol. $159,218-21$.

BOUZID, M., K. HALAI, D. JEFFREYS, P. R. HUNTER (2015):. The prevalence of Giardia infection in dogs and cats, a systematic review and meta-analysis of prevalence studies from stool samples. Vet. Parasitol. 207, 181-202.

BRGLEZ, J., Z. ŽELEZNIK (1976): Ein Übersicht über die Parasiten der Wildkatze (Felis silvestris Schreber) in Slowenien. Z. Jagdwiss. 22, 109-112.

BRIANTI, E., G. GAGLIO, S. GIANNETTO, G. ANNOSCIA, M. S. LATROFA, F. DANTASTORRES, D. TRAVERSA D. OTRANTO (2012): Troglostrongylus brevior and Troglostrongylus subcrenatus (Strongylida: Crenosomatidae) as agents of broncho-pulmonary infestation indomestic cats. Parasit. Vectors. 5, 178.

BURT, M. D., A. W. PIKE, L. K. CORBETT (1980): Helminth parasites of wild cats in north-east Scotland. J. Helminthol. 54, 303-308.

CACCIÒ, S. M., R. BECK, A. ALMEIDA, A. BAJER, E. POZIO (2010): Identification of Giardia species and Giardia duodenalis assemblages by sequence analysis of the 5.8S rDNA gene and internal transcribed spacers. Parasitology 137, 919-925.

CASTRO, O., J. M. VENZAL, M. L. FÉLIX (2009): Two new records of helminth parasites of domestic cat from Uruguay: Alaria alata (Goeze, 1782) (Digenea, Diplostomidae) and Lagochilascaris major Leiper, 1910 (Nematoda, Ascarididae). Vet. Parasitol. 160, 344-347.

ECKERT, J., K. T. FRIEDHOFF, H. ZAHNER, P. DEPLAZES (2005): Lehrbuch der Parasitologie für die Tiermedizin. Enke Verlag Stuttgart, 2. Aufl., 632p.

FUNK, S. M., C. V. FIORELLO, S. CLEAVELAND, M. E. GOMPPER (2001): The role of disease in carnivore ecology and conservation. In: Carnivore Conservation (Gittleman, J. L., S. M. Funk, D. Macdonald and R. K. Wayne, Eds). Cambridge University Press, Cambridge, pp. 443-466.

HRČKOVA, G., M. MITERPÁKOVÁ, A. O’CONNOR, V. ŠNÁBEL, P. D. OLSON (2011): Molecular and morphological circumscription of Mesocestoides tapeworms from red foxes (Vulpes vulpes) in central Europe. Parasitology 138, 638-647. 
JAKŠIĆ, S., S. UHITIL, M. VUČEMILO (2002): Nachweis von Mesozerkarien des Saugwurm Alaria alata im Wildschweinefleisch. Z. Jagdwiss. 48, 203-207.

JANICKI, Z., A. SLAVICA, D. KONJEVIĆ, K. SEVERIN (2007): Game zoology. Faculty of Veterinary Medicine, University of Zagreb, Zagreb.

KIRKOVA,Z., E. RAYCHEV, D. GEORGIEVA(2011): Studies on feeding habits and parasitological status of red fox, golden jackal, wild cat and stone marten in Sredna Gora, Bulgaria. J. Life Sci. 5, 264-270.

KNAUS, M., I. KUSI, D. RAPTI, D. XHAXHIU, R. WINTER, M. VISSER, S. REHBEIN (2011). Endoparasites of cats from the Tirana area and the first report on Aelurostrongylus abstrusus (Railliet, 1898) in Albania. Wien. Klin. Wochenschr. 123 (Suppl 1), 31-35.

KRONE, O., O. GUMINSKY, H. MEINIG, M. HERRMANN, M. TRINZEN, G. WIBBELT (2008): Endoparasite spectrum of wild cats (Felis silvestris Schreber, 1777) and domestic cats (Felis catus L.) from the Eifel, Pfalz region and Saarland, Germany. Eur. J. Wildl. Res. 54, 95-100.

LEPLE, D. (2001): Parasitologie compareé du chat forestier (Felis silvestris silvestris, Schreber 1777) et du chat domestique (Felis catus, Linne 1758), Ecole Nat. These de Doctorat Vét, Lyon.

LUCIO-FORSTER, A, D. D. BOWMAN (2011): Prevalence of fecal-borne parasites detected by centrifugal flotation in feline samples from two shelters in upstate New York. J. Feline Med. Surg. 13, 300-303.

MEHLHORN, H., D. DÜWEL, W. RAETHER (1993): Diagnose und Therapie der Parasitosen von Haus-, Nutz- und Heimtieren, Gustav Fischer Verlag Stuttgart, Stuttgart, Jena New York, $529 \mathrm{p}$.

MIRCEAN, V., A. TITILINCU, C. VASILE (2010): Prevalence of endoparasites in household cat (Felis catus) populations from Transylvania (Romania) and association with risk factors. Vet. Parasitol. 171, 163-166.

NAPOLI, E., S. ANILE, C. ARRABITO, D. SCORNAVACCA, M. V. MAZZAMUTO, G. GAGLIO, D. OTRANTO, S. GIANNETTO, E. BRIANTI (2016): Survey on parasitic infections in wildcat (Felis silvestris silvestris Schreber, 1777) by scat collection. Parasitol. Res. 115, 255-261.

PAPADOPOULOS, H., C. HIMONAS, M. PAPAZAHARIADOU, K. ANTONIADOUSOTIRIADOU (1997): Helminths of foxes and other wild carnivores from rural areas in Greece. J. Helminthol. 71, 227-231.

POZIO, E., L. RINALDI, G. MARUCCI, V. MUSELlA, F. GALATI, G. CRINGOLI, P. BOIREAU, G. LA ROSA (2009): Hosts and habitats of Trichinella spiralis and Trichinella britovi in Europe. Int. J. Parasitol. 39, 71-79.

RAJKOVIĆ-JANJE, R., A. MARINCULIĆ, S. BOSNIĆ, M. BENIĆ, B. VINKOVIĆ, Ž. MIHALJEVIĆ (2002): Prevalence and seasonal distribution of helminth parasites in red foxes (Vulpes vulpes) from the Zagreb County (Croatia). Z. Jagdwiss. 48, 151-160.

RODRIGUEZ, A., E. CARBONELL (1998): Gastrointestinal parasites of the Iberian lynx and other wild carnivores from central Spain. Acta Parasitol. 43, 128-136. 
RODRÍGUEZ-PONCE, E., J. F. GONZÁLEZ, M. CONDE DE FELIPE, J. N. HERNÁNDEZ, J. RADUAN JABER (2016): Epidemiological survey of zoonotic helminths in feral cats in Gran Canaria island (Macaronesian archipelago-Spain). Acta Parasitol. 61, 443-450.

SCHMÄSCHKE, R. (2013): Die koproskopische Diagnostik von Endoparasiten in der Veterinärmedizin, Schlütersche Verlag, Hannover, p. 152.

SCHUSTER, R., D. HEIDECKE, K. SCHIERHORN (1993): Contributions to the parasite fauna of local hosts. 10. On the endoparasitic fauna of Felis silvestris. Appl. Parasitol. 34, 113-120.

SHOOP, W. L., K. C. CORKUM (1987): Maternal transmission by Alaria marcianae (Trematoda) and the concept of amphiparatenesis. J. Parasitol. 73, 110-115.

SINDIČIĆ, M, M. JAGIĆ, N. ŠPREM, V. SLIJEPČEVIĆ, R. POPOVIĆ, D. KONJEVIĆ (2016): Diversity of mitochondrial DNA in wildcats in Croatia - preliminary results. Proceedings of Sixth Croatian Veterinary Congress with International Participation, 26 - 29 October, Opatija, Croatia pp. 333-340.

SINDIČIĆ, M., F. MARTINKOVIĆ, M. BUJANIĆ, N. TUŠKAN, M. ŠPEHAR, D. KONJEVIĆ (2017): Morphological and molecular identification of golden jackal parasites. Book of abstracts. $7^{\text {th }}$ International Congress „Veterinary Science and Profession“, 5 - 7 September, Zagreb, Croatia, p. 77.

SPEARE, R., D. J. TINSLEY (1987): Survey of cats for Strongyloides felis. Aust. Vet. J. 64, 191.

TAKÁCS, A., L. SZEMETHY, M. HELTAI, A. A. TAKÁCS (2011): Data on the parasitological state of wild cats (Felis silvestris Schreber 1777) and of their hybrids with feral domestic cats (Felis silvestris catus L. 1758) on Hungarian hunting areas. Hungar. Vet. J. 133, 670-674.

TAKEUCHI-STORM, N., H. MEJER, M. N. AL-SABI, C. S. OLSEN, S. M. THAMSBORG, H. L. ENEMARK (2015a): Gastrointestinal parasites of cats in Denmark assessed by necropsy and concentration McMaster technique. Vet. Parasitol. 214, 327-332.

TAKEUCHI-STORM, N., M. N. AL-SABI, S. M. THAMSBORG, H. L. ENEMARK (2015b): Alaria alata Mesocercariae among Feral Cats and Badgers, Denmark. Emerg. Infect. Dis. 21, 1872-1874.

THAMSBORG, S. M., J. KETZIS, Y. HORII, J. B. MATTHEWS (2016): Strongyloides spp. infections of veterinary importance. Parasitology 144, 1-11.

DOI: $10.1017 / \mathrm{S} 0031182016001116$

VERONESI, F., D. TRAVERSA, E. LEPRI, G. MORGANTI, F. VERCILLO, D. GRELLI, R. CASSINI, M. MARANGI, R. IORIO, B. RAGNI, A. DI CESARE (2016): Occurrence of lungworms in european wildcats (Felis silvestris silvestris) of central Italy. J. Wildl. Dis. 52, 270-278.

WAID, D. D., D. B. PENCE (1988): Helminths of mountain lions (Felis concolor) from southwestern Texas, with a redescription of Cylicospirura subaequalis (Molin, 1860) Vevers, 1922. Can. J. Zool. 66, 2110-2117. 
YAMAGUCHI, N., A. KITCHENER, C. DRISCOLL, B. NUSSBERGER (2015): Felis silvestris. The IUCN Red List of Threatened Species 2015, e.T60354712A50652361. DOI: 10.2305/IUCN.UK.2015-2.RLTS.T60354712A50652361.en

\section{MARTINKOVIĆ, F., M. SINDIČIĆ, S. LUČINGER, I. ŠTIMAC, M. BUJANIĆ, T.ŽIVIČNJAK, D.STOJČEVIĆ JAN, N.ŠPREM, R. POPOVIĆ, D. KONJEVIĆ: Endoparaziti u divljih mačaka u Hrvatskoj. Vet. arhiv 87, 713-729, 2017.}

SAŽETAK

Znanstveni radovi o parazitima divljih mačaka (Felis silvestris silvestris) rijetki su i najčešce rađeni na malom broju uzoraka te je stoga naš cilj bio istražiti učestalost endoparazita divljih mačaka u Hrvatskoj. Pregledali smo lešine 34 divlje mačke, stradale u prometu ili u sklopu provedbe lovnogospodarskih osnova. Sve su životinje bile negativne na bjesnoću. Sadržaj želudca i crijeva pregledali smo pod mikroskopom. Izmet iz debelog crijeva pregledan je metodom flotacije pomoću zasićene otopine $\mathrm{ZnSO}_{4}$, dok je dijafragma pregledana pomoću umjetne probave. Upotrijebili smo izravnu imunofluorescenciju za utvrđivanje cista Giardia sp., što je prvo takvo istraživanje kod divljih mačaka. Sve pregledane životinje bile su invadirane barem jednom vrstom parazita, dok je najraznolikija invazija uključivala šest različitih vrsta parazita utvrđenih kod jedne životinje. Sljedeće su vrste parazita identificirane (\% prevalencije odraslih parazita i razvojnih stadija u svim analiziranim uzorcima): Taenia taeniaeformis (55,9 \%), Capillaria sp. (50 \%), Toxocara cati (50 \%), Isospora sp. (29,4 \%), Strongyloides sp. (23,5\%), Giardia sp. (17,6\%), Ancylostoma tubaeformae (14,7\%), Physaloptera sp. (11,8 $\%)$, Hymenolepididae (8,8\%), Alaria alata (5,9\%), Aelurostrongylus abstrusus (5,9\%), Toxascaris leonina (5,9 $\%)$, Trichinella sp. (5,9\%), Mesocestoides lineatus (5,9 \%), Anoplocephalidae (2,9\%), Dipylidium caninum (2,9 \%), Trichuris sp. (2,9 \%), Isospora felis (2,9\%), Eimeria sp. (2,9\%) i Sarcocystis sp. (2,9\%). Među njima, Eimeria sp., Trichuris sp., jaja anoplocefalida i himenolepidida su pseudoparaziti, koji potječu od plijena. Četiri roda koje smo identificirali do sada nisu nikada opisani kod divljih mačaka - Giardia sp., Strongyloides sp., Sarcocystis sp. i Dipylidium caninum.

Ključne riječi: paraziti, divlja mačka, Felis silvestris silvestris, Hrvatska 
